Language in Africa 1(3), 2020, 181-215. doi: 2686-8946-2020-1-3-181-215

\title{
THE BUA GROUP NOUN CLASS SYSTEM: LOOKING FOR A HISTORICAL INTERPRETATION
}

\author{
Pascal Boyeldieu \\ CNRS, UMR 8135 Langage, Langues et Cultures d'Afrique \\ pascal.boyeldieu@cnrs.fr \\ Raimund Kastenholz \\ Johannes Gutenberg-Universität, Mainz \\ kastenho@uni-mainz.de \\ Ulrich Kleinewillinghöfer \\ Johannes Gutenberg-Universität, Mainz \\ kleinewi@uni-mainz.de \\ Florian Lionnet \\ Princeton University \\ flionnet@princeton.edu
}

\begin{abstract}
The way Bua languages express number on nouns mostly consists of alternating suffixes that bear witness of a former classification system. However, Kulaal is the only present-day language where these markers are not frozen but actually trigger agreement with free, optional determiners that follow the noun and may show some formal affinity with its suffix. For several reasons, previous attempts at reconstructing a historical noun morphology common to all Bua languages considered the sole suffixes and neglected the determiners present in Kulaal. But, as is argued in the present paper, more recent data show that, in some cases, presentday suffixes may result from the association of a former suffix with an element similar to one of the Kulaal determiners. In such cases the former determiner has simply lost its independence and been historically stacked onto the noun form.
\end{abstract}

Key words: historical linguistics, morphology, noun classes, agreement, suffix, determiner, stacking, Bua languages, Adamawa languages 


\section{The Bua languages}

The Bua languages are spoken by small groups living in southern Chad. They comprise some 13 units, some of which are now extinct but known through limited wordlists collected in the 1970s (see the map on Figure 1). ${ }^{1}$ These languages are as follows, see Table 1. Endonyms are in italics; extinct languages are indicated in square brackets; a rough estimate of the number of speakers is given in the right column. ${ }^{2}$

Table 1

\section{The Bua languages}

\begin{tabular}{lc}
\hline Language name & Number of Speakers \\
\hline Lua or Nielim, Niellim & 5.000 \\
[Cini] & - \\
Tun or Tunya, Tounia & 2.000 \\
{$[$ Perim $]$} & - \\
{$[$ Lo⿰ or Noy] } & - \\
Ba or Bua, Boua & 8.000 \\
Kawãwãy or Korom (?) & 60 \\
Kulaal or Iro Gula, Goula d'Iro & 3.500 \\
Kulaale or Eyle, Fanya, Fanian & 1.000 \\
Zan Gula, Goula de Zan (More) & 3.200 \\
Bon Gula, Goula de Bon (Eeni) & 1.200 \\
Bolgo (including Tereu, Bolgo, Bormo) & 2.800 \\
Koke & 600 \\
\hline
\end{tabular}

Endonyms - for which some uncertainty may remain - often differ from the most widespread language names. Differences between

${ }^{1}$ For a more detailed presentation of the Bua Group languages, see Boyeldieu, Kastenholz, Kleinewillinghöfer \& Lionnet (2018).

${ }^{2}$ The authors are grateful to the editors and reviewers of the present paper for their careful reading as well as for their advices, suggestions, and support. 


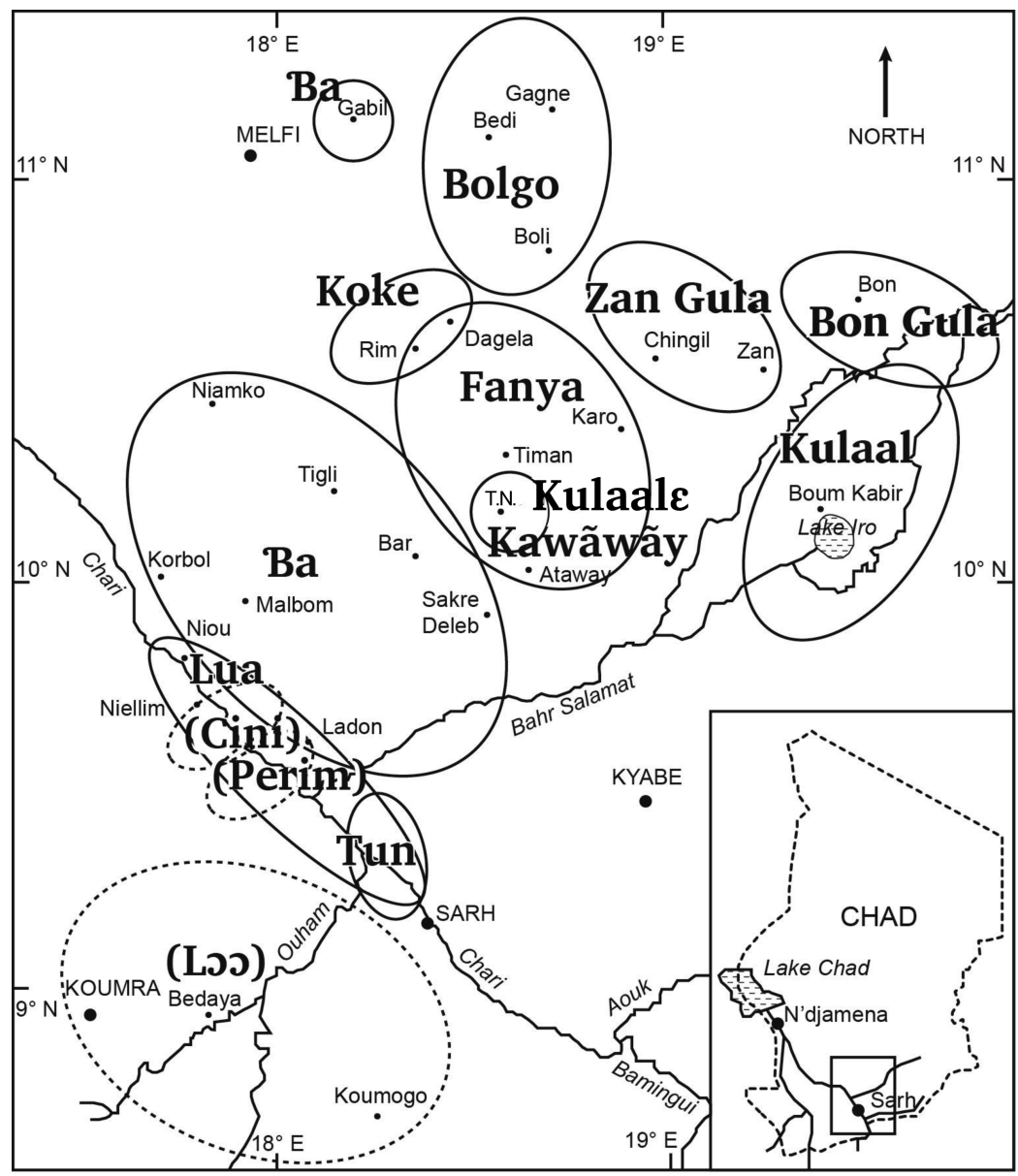

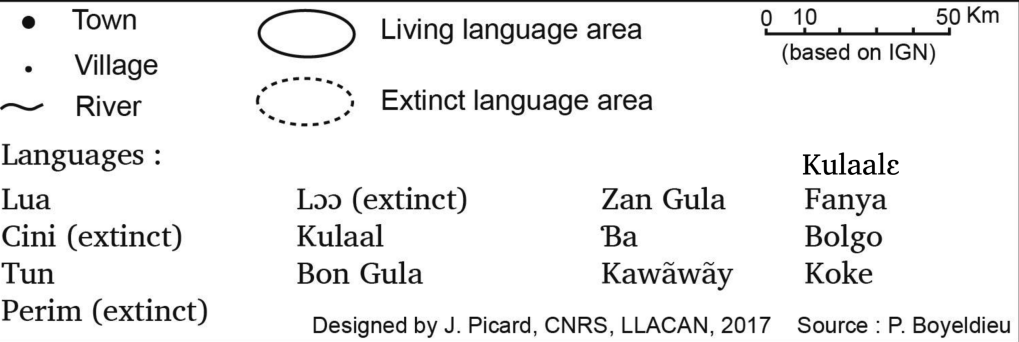

Figure 1. Distribution of the Bua languages in Southern Chad 
dialects and separate languages may also be uncertain. Thus, Kawãwãy might represent a variety of Ba. Also Bolgo and Koke might constitute two (or more) variants of the same language.

Although used in two neighbouring but different languages, the similarity of the two endonyms Kulaal and Kulaale is not fortuitous.

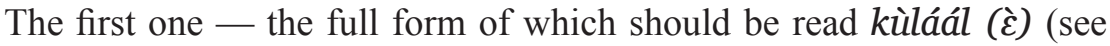
footn. 5) - refers to the language spoken by the Iro Gula (see also kùláá (kù) /pl. kùléé (kì) 'human being, Iro Gula'). The second one - [kùlá:lè] /pl. [kùlárù], which might be an adjective? — refers to the language also known as Fanya. As will be shown in $\S 4$ below, the latter, in fact, results from the historical fixation of a former postposed agreement determiner - $(l) \grave{\varepsilon}-$ that is still free in the former.

The Bua languages as a whole are poorly documented. The relatively best known languages are Kulaal, Lua, Ba, Bolgo, Zan Gula, and Kulaale. Sources, of uneven quantity and quality, partially consist of unpublished data. They mainly concern lexicon and morphology, with limited information on syntax. Our transcriptions usually respect the conventions adopted in the different sources.

Geographically these languages represent the easternmost extension of the Adamawa languages, a situation which is of special interest from both linguistic and historical points of view.

\section{Reconstructing the noun class system: the 2018 attempt and its limits}

Bua languages as a whole show morphological traces of a former noun class system. Indeed, in every language, a more or less important part of the noun lexicon may display various alternating, internal and/or final segments that chiefly express a contrast of number and clearly represent altered forms of a previous system of suffixed markers. Examples from Tun are illustrated in (1): 
(1) Tun (Palayer 1975)

sg. $t \bar{\varepsilon} \bar{\varepsilon}$ pl. têm 'country, village'

jéćlé júlíl 'filter'

tōy tōn 'ear'

Only one present-day language, namely Kulaal, has, in addition, a system of separable, independent concord markers, also termed 'determiners', that may follow the noun and, to some extent, show phonic affinities with the presumably older suffixes (therefore, Kulaal is the only Bua language that may be regarded as a class language in the strict sense). This situation is illustrated in (2) (agreement determiners are transcribed in brackets):

(2) Kulaal (Pairault 1966; 1969)

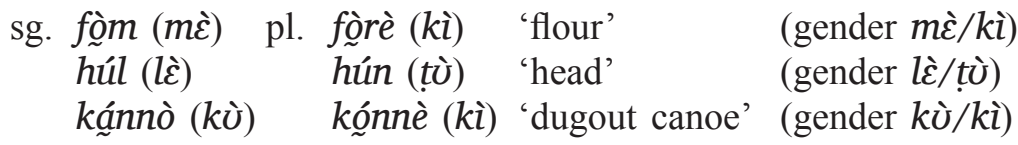

An early attempt to reconstruct the historical noun morphology of the Bua languages (Boyeldieu 1983; 2014) concentrated on the presumed suffixes only and totally disregarded possible cognate forms of the Kulaal concord markers that were in fact not detectable, at that time, in the data available for the other languages of the Group.

A more recent attempt (Boyeldieu, Kastenholz, Kleinewillinghöfer \& Lionnet 2018, henceforth BKKL 2018) was made by the authors of the present paper who could integrate a fair amount of new data on several languages, in particular Zan Gula and Kulaale/Fanya, that contain vital clues for a different analysis of the historical Bua Group noun morphology. However, the full consequences of these new pieces of information were not totally clear - or understood - at the time of writing and the following extract gives evidence of our unsureness:

"[...] there is currently no sign that any other language than Kulaal has a set of free, separable agreement markers justifying the status of a noun class language. On the other hand, it is not excluded that traces 
of such concord morphemes can still be detected in some cases: as first observed by Raimund Kastenholz, one wonders whether, for some languages, a number of forms might not have been transcribed together with elements that (diachronically or synchronically) probably correspond to Kulaal determiners." (BKKL 2018: 79)

In particular, and as shown in Table 11 at the end, we considered the two reconstructed genders ${ }^{*}-l /{ }^{*}-n$ and ${ }^{*}-l E /{ }^{*}-r U$ as in complementary distribution depending on the language (BKKL 2018: 103) whereas, with the benefit of hindsight, we will regard them here as one and the same gender *-l_le/*-n_du.

Nevertheless, before going into the details of this new analysis, it is necessary to present the system of Kulaal (Pairault 1966; 1969; Boyeldieu 1986; Kleinewillinghöfer 2017; BKKL 2018), which is probably, with respect to noun morphology, the most conservative and consequently the best witness of the historical noun class system common to all Bua languages.

\section{Kulaal noun number marking and class agreement}

If we except some rare cases of invariable forms (e.g. tè̀m $(k \grave{c}) / p 1$. tè̀m (kì) 'African mistletoe, Loranthus sp.', pòròàsíi (kè) /pl. pòròàsî́ (ki) 'type of pot'), and abstracting from the optional concord markers that will be treated later under iv.), Kulaal nouns are marked for number by way of various and numerous devices that belong to two main types, possibly combined.

i) The noun plural form may be marked by a raising of the root vowel. ${ }^{3}$ As illustrated in (3) this Umlaut is sometimes the only one device involved, i.e. no suffixation is present. Note that, as mentioned above, and in accordance with Pairault $(1966 ; 1969)$, the transcription

${ }^{3}$ Pairault (1966: 422; 1969: 44-46) presents the Kulaal vowel system as contrasting $/ i, \imath, e, \varepsilon, a, \jmath, o, U, u /$, augmented with two correlations of length and nasality, the nasal contrasts being, however, limited to $/ \underset{\sim}{e} \underset{\sim}{a}, \underset{\sim}{\alpha} /$. 
of nouns in isolation is followed by their agreement determiner in parentheses (see below). ${ }^{4}$

\begin{tabular}{|c|c|c|}
\hline kî̀p $(k \grave{\varepsilon})$ & pl. kûp (kì) & 'crocodile' \\
\hline l’̀̀̀m $(k \grave{)})$ & lòòm (kì) & $\begin{array}{l}\text { 'Parkia biglobosa } \\
\text { (locust bean tree)' }\end{array}$ \\
\hline mààtí $(k \hat{\varepsilon})$ & mòòtí (kì) & 'throwing knife' \\
\hline híríkè $(k \grave{\varepsilon})$ & híríkè (kì) & 'pagne, wrapper, women's cloth' \\
\hline நàñ $(k \grave{\varepsilon})$ & yòñ $(k i)$ & 'chief, headman' \\
\hline kứrààm (kù) & kúrèèm (kì) & 'watchtower' \\
\hline
\end{tabular}

Obviously, this raising of the root vowel resulted from the presence of a former high — probably +ATR - vowel in the plural suffix (see ii) below) but most likely the process later extended to other nouns under the pressure of analogy.

ii) The plural form may be marked by alternating final segments that have the nature of a suffix (and may be $\emptyset$ ). This device, which is slightly more frequent, may work alone, i.e. without Umlaut, as in (4).

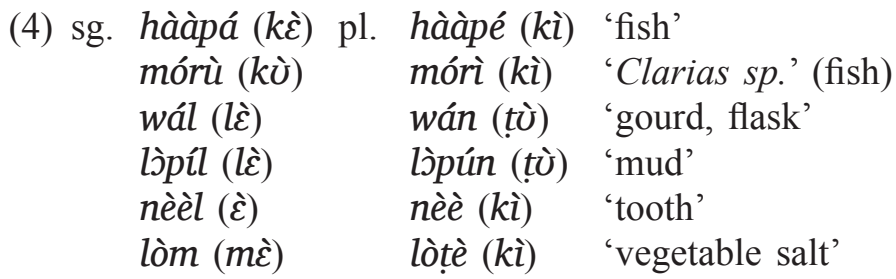

iii) In most cases, however, the two processes, Umlaut and suffix alternation, are combined, as in (5).

\begin{tabular}{|c|c|c|}
\hline sg. kj̀là $(k \hat{\varepsilon})$ & pl. kòlè (kì) & 'Ficus thonningii' (tree \\
\hline (kù) & tòòlì (kì) & 'molar' \\
\hline$h \grave{\varepsilon l}(\grave{\varepsilon})$ & hèn (țù) & 'African rock python' \\
\hline$(\grave{\varepsilon})$ & móó (kì) & 'breast' \\
\hline hắm $(m \hat{\varepsilon})$ & hóți (kì) & 'beer' \\
\hline
\end{tabular}

${ }^{4}$ For the sake of legibility, however, we introduce a space between the noun itself and its determiner, e.g. sg. kî̀p $(k \grave{\varepsilon}) / p l$. kî̀p (kì) 'crocodile' instead of the original sg. kî̀p $(k \dot{\varepsilon}) /$ pl. kî̀ $(k \grave{i})$. 
Note that in both (4) and (5), the five alternating sg./pl. suffixes are easily identified as $-a /-e,-u /-i,-v /-i,-l /-n,-\imath l /-u n,-l /-\varnothing$, and $-m /-t e \sim t i$. But there are no detectable suffixes in (3) where the final segments do not alternate. And what about such cases as in (6) below, where former vocalic suffixes possibly merged with the root vowel into an indivisible, short or long vowel phoneme?

\begin{tabular}{|c|c|c|}
\hline kù) & pl. hó (kì) & 'year' \\
\hline . & tú $(k i)$ & 'ear' \\
\hline & kóoِ (kì) & 'heron' \\
\hline 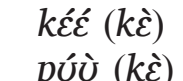 & $\begin{array}{l}\text { kéé (ki) } \\
\text { púù (kì) }\end{array}$ & $\begin{array}{l}\text { 'Maerua angolensis' (tree) } \\
\text { 'goat' }\end{array}$ \\
\hline
\end{tabular}

One should in fact consider that the notion of suffix is above all historical. If in many cases present-day reflexes of former suffixes are still obvious and transparent, for some nouns they seem to be closely amalgamated with the root. And further nouns probably never had a suffix, namely those whose final segments do not distinctly fit their agreement determiner (see below). This is clearly the case, at least, for recent borrowings that nevertheless fall into the agreement system and may even display an Umlaut that they necessarily acquired through analogical alignment. See illustrations in (7):
(7) sg. kóóp $(k \bar{\varepsilon})$
pl. kóóp (ki)
'drinking metal cup' $(<$ Arabic)
kúpúk (kò)
kúpík (kì)
'strip of woven cotton'
kásáás $(k \grave{\varepsilon})$
káséés (ki) 'bottle' $(<$ Arabic)
ásèkàr $(k \hat{\varepsilon})$
ásèkèr (ki)
'soldier' $(<$ Arabic $)$
mòntòlóós $(k \grave{)}$
pàntèléés $(k i)$
'(European) trousers' $(<$ French)

iv) Moreover, and as already illustrated in the preceding examples, Kulaal has a system of postposed agreement determiners that usually come in sg./pl. pairs and are clearly, although not absolutely, correlated with the final segment(s) - i.e. suffixes - of the noun they modify. 
These non-obligatory déterminatifs classificatoires (Pairault 1966: 421-437; 1969: 261-278) may add a definite or deictic value to the noun. They also work alone as deictic substitutes (Houis 1967: 125-129). Clearly, they are representative of noun classes, even if some of these prove to be reduced and vestigial.

Table 2 below summarizes the organisation of the determiners in classes and genders and indicates their respective frequency. Note that sequences of identical consonants being excluded after long vowels,

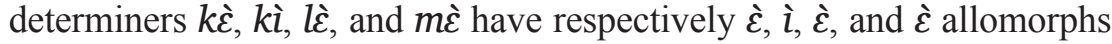
in this context. By convention, graphic vowels following hyphens may represent here short or long final vowels (e.g. - $\supset(k \grave{)})$ for both - $(k \grave{)})$ and $-\supset \supset(k \grave{u})) .{ }^{[V]}$ and ${ }^{[V V]}$ symbolize preceding short or long vocalic context.

Table 2

Kulaal noun classes, genders, and agreement determiners

(BKKL 2018: 75 [revised])

\begin{tabular}{|c|c|c|}
\hline $\begin{array}{l}\text { Class / gender } \\
\text { determiners }\end{array}$ & $\begin{array}{l}\text { Main final segments in nouns } \\
\text { (mostly historical suffixes) } \\
\text { and realisation of determiner }\end{array}$ & $\begin{array}{l}\text { Lexical } \\
\text { tokens }\end{array}$ \\
\hline$k \grave{u} / k i ̀$ & 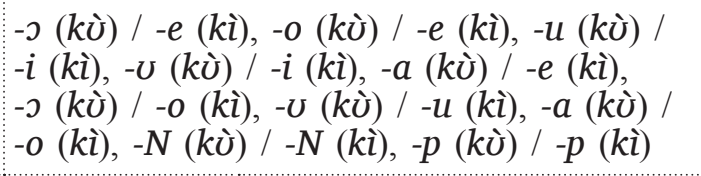 & 332 \\
\hline$k \grave{\varepsilon} / k i ̀$ & 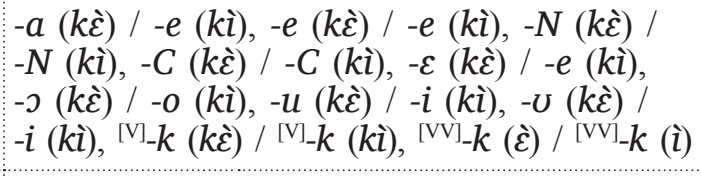 & 240 \\
\hline$l \grave{\varepsilon} / t ̦ \grave{v}$ & 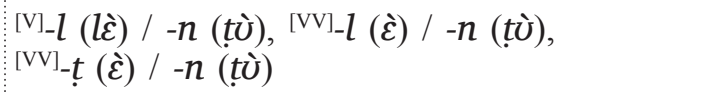 & $\begin{array}{l}144 \\
(227 ?)^{5}\end{array}$ \\
\hline$k \grave{\varepsilon} /-$ & & 120 \\
\hline
\end{tabular}

${ }^{5}$ Pairault's data contain many nouns, the determiners of which are not mentioned. This is often the case for nouns ending in sg. $-l / p l . ~-n$ (or sg.-only $-l$ ) that presumably belong to gender $l \grave{\varepsilon} / t \underline{v}$ or to singular-only class $l \grave{\varepsilon} /-$. 
End of Table 2

\begin{tabular}{|c|c|c|}
\hline $\begin{array}{l}\text { Class / gender } \\
\text { determiners }\end{array}$ & $\begin{array}{l}\text { Main final segments in nouns } \\
\text { (mostly historical suffixes) } \\
\text { and realisation of determiner }\end{array}$ & $\begin{array}{l}\text { Lexical } \\
\text { tokens }\end{array}$ \\
\hline$k \grave{U} /-\quad($ sg. only $)$ & & 69 \\
\hline lì/- $\quad$ (sg. only) & & $\begin{array}{l}36 \\
(67 ?)\end{array}$ \\
\hline$-/ k i \quad$ (pl. only) & & 35 \\
\hline$-/ t \grave{े} \quad$ (pl. only) & & 17 \\
\hline$l \grave{\varepsilon} / k \grave{\imath}$ & ${ }^{[\mathrm{V}]}-l(l \grave{\varepsilon}) /-n(k \grave{)}) \sim-t+e[k \grave{i}],{ }^{[\mathrm{Vv}]}-l(\grave{\varepsilon}) /-\emptyset(k \grave{i})$ & 9 \\
\hline$m \grave{\varepsilon} / k \grave{~}$ & $\begin{array}{l}{[\mathrm{V}]_{-m}(m \grave{\varepsilon}) /} \\
{[\mathrm{VV}]_{-m}(\hat{\varepsilon}) /}\end{array}$ & 7 \\
\hline 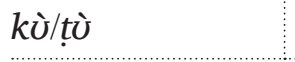 & & 4 \\
\hline$m \grave{\varepsilon} /-\quad$ (sg. only) & & 4 \\
\hline sう̀/mè ? & $? /-m(m e ̀)$ & 2 \\
\hline$-/ m \grave{e} ?$ (pl. only) & & 1 \\
\hline kí/mò & $? /-m(m o ̀)$ & 1 \\
\hline$k \grave{\varepsilon} / m o ̀$ & $? /-m(m o ̀)$ & 1 \\
\hline Unknown & & $\begin{array}{l}236 \\
(122 ?)\end{array}$ \\
\hline Total & & 1258 \\
\hline
\end{tabular}

As may be observed, the sound correlation between the final segments/suffixes and the determiners is clear and regular in the cases of sg. $-l$ and $l \grave{\varepsilon}$, pl. $-n$ and ț̀े, sg. $-m$ and $-m \grave{\varepsilon}$, and pl. $-R i \sim e$ and $k \grave{\text {, }}$ which represent the most conservative — and morphologically stable classes / genders. By contrast, sg. $k \hat{\varepsilon}$ mostly agrees with noun final $-a$, $-\varepsilon$ or $-e$ but also with a final consonant $(-N$ for $-m,-n,-\tilde{n},-\eta$ or $-C$ 
for $-k,-p,-r,-s,-t,-t,-y)$, more rarely with a final back vowel $(-\supset$, $-u,-U)$. Sg. kù mostly agrees with a back vowel $(-0,-o,-U,-U)$ but very often also with an $-a$ (just like $k \grave{\varepsilon}$ !), and sometimes with a consonant $(-m,-\eta,-p)$. As for pl. kì, it mainly agrees with the final vowels $-e$ or $-i$ (rarely $-o$ or $-u$ ) but also with the same final consonants as sg. $k \grave{\varepsilon}$ or $k \grave{u}$. As already mentioned, classes $k \grave{\varepsilon}, k \grave{u}$, and $k \grave{i}$ - as well as resulting genders $k \grave{\varepsilon} / k \grave{k}$ and $k \grave{u} / k \grave{i}$ - turn out to be the most active and changing ones, possibly involving historical class/gender shifts and obviously welcoming items of foreign / recent origin.

In relation to Kulaal's forms, we distinguish two groups of Bua languages that are illustrated here as follows (see the map on Figure 1):

- Group A: Zan Gula, Fanya, and Kulaal $\varepsilon^{6}$

- Group B: Lua, Bon Gula, and Bolgo

The argumentation developed in the coming $\S 4$ and $\S 5$ refers to the comparative series (CS) displayed in the Appendix and presenting noun forms usually paired by number 'sg. / pl.'. Note, however, that

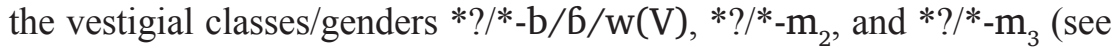
BKKL 2018: 103) are not treated in this paper. As for the vowel raising - or Umlaut -, it will not be mentioned any further and its presence is omitted in the reconstructed class/gender forms cited below but reintroduced (as $\{\hat{\}}\}$ ) in Table 11 at the end.

\section{Group A languages}

The general assumption is that these languages underwent a process of stacking and fixation (or lexicalization) of a former postposed agreement element similar to the present-day determiners of Kulaal. As a result, establishing regular correspondences in the noun morphology requires comparing the current suffixes of languages not with the mere suffixes of Kulaal, but with the different sequences of suffix+determiner that may be observed in that language.

6 We preserved here the two names Fanya and Kulaale in relation with two distinct sources that most probably refer to the same language (see Appendix). 
However, if the correspondences are obvious in certain cases, they are more disputable in other ones. The different situations will be commented below according to the different classes.

\subsection{Class *-l_le (sg.)}

As illustrated in CS 1-7 and 12-13, Group A languages display complementary sequences of the ${ }^{[V]}-l l \varepsilon$ or ${ }^{[V V]}-l \varepsilon$ type ${ }^{7}$ that parallel the complementary Kulaal ${ }^{[V]}-l(l \grave{\varepsilon}),{ }^{[V V]_{-}} l(\grave{\varepsilon})$, or ${ }^{[V V]_{-}} \underline{t}(\grave{\varepsilon})$ realizations. In both cases the complementarity is conditioned by the fact that geminated or, respectively, sequences of the same consonants are excluded in the context of a preceding long vowel. However, Group A languages contravene

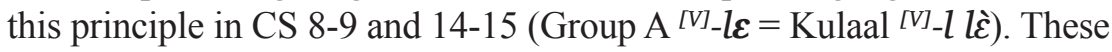
series then behave in an irregular way that is unexplained so far.

Reflexes of *-l_le are illustrated in CS 10.

\subsection{Class *-n_du (pl.)}

Similarly, Group A languages have complementary sequences of the

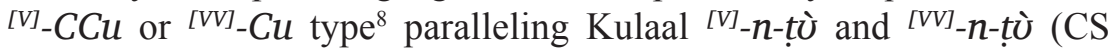
1-6). Again, most Groupe A languages are irregular in having an unexplained single consonant after a short vowel $\left({ }^{[\mathrm{V}]} \mathrm{Cu}\right)$ in $\mathrm{CS} 8-9$.

Reflexes of *-n_du are illustrated in CS 11 . Note that in some cases, both *-n_du and *-I_ki may represent, according to languages, the historical plural of a singular *-l_le (CS 3, 13, and 15, for Kulaal and Group A languages, at least).

\subsection{Class * $\boldsymbol{m}_{1-} m \varepsilon$ (formally sg.)}

CS 16-17, 19, and 21-24 illustrate correspondences of Kulaal sequences ${ }^{[V]_{-}} m(m \grave{\varepsilon})$ and ${ }^{[V V]_{-}}-m(\grave{\varepsilon})$ with Group A languages forms of the ${ }^{[V]}-m i / e$

${ }^{7}$ The actual vowel reflexes vary between $\varepsilon$ and $e$. Zan Gula $d$ and FanyaKulaale $r$ usually correspond to Kulaal $t$ (CS 6-7): most probably the historical class should be characterized with two complementary forms, i.e. ${ }^{*}-\underline{l} l \varepsilon$ and ${ }^{*} d \_d \varepsilon$.

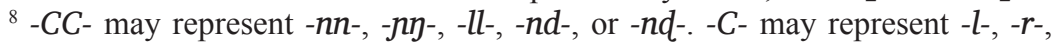
or $-r-$. The vowel is $u$ or $v$ (Zan Gula, Kulaale) and $u$ or $o$ (Fanya). 
or ${ }^{[V V]}-m i / e$ type. Although no case of geminated $-m m$ - is attested here (except for Fanya in CS 19 and the problematic Kulaale tómmú in CS 22 ), we assume that the final vowel $-i / e$ again results from the historical fixation of a former determiner similar to the Kulaal one $(m \grave{\varepsilon} \sim \grave{\varepsilon})$. The same probably holds for CS 20 and 22-23 although no cognate form is attested in Kulaal.

Reflexes of $*-m_{1-} m \varepsilon$ are illustrated in CS 27.

\subsection{Class *-( $\left.m_{1}-\right) r i \_k i$ (formally $\left.\mathrm{pl}.\right)$}

CS 17-18 and 25 show that the Kulaal sequences -tii (ki) and -(n)te (ki) correspond to Zan Gula -dey or -dey (no attestation is available for the two other Group A languages, Fanya and Kulaale). We assume here that Zan Gula -de- or - $d \varepsilon$ - is cognate with the Kulaal suffix -ți or -(n)te while the final vowel $-y$ is cognate with the Kulaal determiner $k i$. If, as is likely, the historical determiner itself contained a velar stop ( $* k i)$, the evolution towards Zan Gula $-y$ entails a total lenition of this consonant, a sound change that will be confirmed, as a result of historical stacking, for all historical determiners containing a velar stop, i.e. *kè, *kù, and *kì (see below).

Reflexes of $*_{-}\left(m_{1}-\right) r i-k i$ are illustrated in CS 28. In several cases (CS 18 and 24-25 but also other instances like fạ̀m $(m \grave{\varepsilon})$ / fọțì $(k i)$ 'milk', fòm $(m \bar{\varepsilon})$ / fọrè $(k i)$ 'flour', as well as plural-only è ètété $(k i)$ 'tears', hàrè̀ (kì) 'cuvée' (= must + marc)', and tínțè (kì) 'dregs of must (malt drink)'), a nasal feature - vowel or consonant $n$ - shows just before the Kulaal suffix -ți/e, suggesting that the latter may have been added - rather than substituted - to the sg. prefix $-m$. Hence the reconstruction of this class as ${ }^{*}-\left(m_{1^{-}}\right) r i k i{ }^{9}$

9 This peculiar plural formation is a strong argument for considering the historical * $m_{1-} m \grave{\varepsilon}$ 'mass / abstract' noun class not as a singular but as a transnumeral class, originally constituting a single class gender. 


\subsection{Class *-A_ke (sg.)}

In CS 29-33, Zan Gula and Kulaale (no cognate is attested for Fanya) mostly display $C V(V) C a$ forms that correspond to the bare noun in Kulaal, i.e. $C V(V) C a$ without the determiner $k \grave{\varepsilon}$. However we cannot exclude that, in some cases at least, historical stacking also happened with class *-A_ks: in CS 34-35, Kulaale forms with final long vowels CVCar could result from the integration of a former * $k \varepsilon$ determiner after the loss of the velar stop. In CS 36 also the trace of the same determiner would show up, with possible assimilation to and gemination of the root final consonant

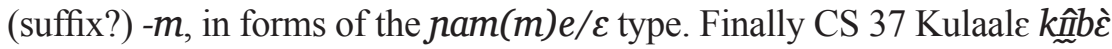
clearly preserves a vocalic trace of the determiner ${ }^{*} k \grave{\varepsilon}$.

Reflexes of *-A_ke are illustrated in CS 38 .

\subsection{Class *- $U_{-} k u$ (sg.)}

In CS 40-47 again, Group A languages display forms $(C V(V) C u / o / s / a)$ that are chiefly parallel to the Kulaal nouns without the determiner $k \dot{v}$. But once again a velar element (-w or $-u)$ may show in cases where the Kulaal noun ends with an $-\varepsilon$, an $-a$, or a consonant (CS 48-51): 48 Kulaale hwè̀w 'moon', 49 Zan Gula rāáw and Kulaale rā̃w 'sky, rain', 50 Zan Gula aaw 'grass' (but 52 Zan Gula láá and Kulaale lá: are counterexamples), 51 Zan Gula sāābù 'wind'. We assume that these segments are reflexes of the determiner $* k u$, the initial velar stop of which was lost.

Reflexes of $*_{-} U_{-} k u$ are illustrated in CS 53 .

\subsection{Class *- $U_{-} k \varepsilon$ (sg.)}

The few illustrations of presumed reflexes of a ${ }_{-} U_{-} k \varepsilon$ class are illustrated in CS 54-57. Fanya data are missing and Zan Gula examples are too limited to be reasonably commented. But Kulaale nouns consistently display a final syllable $-w \varepsilon$ that clearly parallel the Kulaal kè determiner: hyàwwè 'dog', núwwè 'bird' (no Kulaal cognate available), hyợ:lwè 'guinea fowl', and búwè 'goat'.

Reflexes of $*_{-} U_{-} k \varepsilon$ are illustrated in CS 58 . 


\subsection{Class *-I_ki (pl.)}

Illustrations of this class are numerous since it works as a plural class

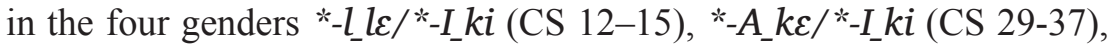
${ }^{*}-U_{-} k u /{ }^{*}-I_{-} k i\left(\mathrm{CS} 40-50\right.$ and 52), and ${ }^{*} U_{-} k \mathcal{E} /{ }^{*}-I_{-} k i(\mathrm{CS} 54-57)$. Fanya is poorly illustrated with CS $12,14,36$, and 47 that deserve the same comments as the similar Kulaale forms (see below).

Kulaale may display forms that are similar to the Kulaal bare noun - i.e. they do not reveal any clear trace of the *ki determiner, e.g. CS 30 hỹò̀:bè, 44 wéllé, or 47 Rúwé - but in several cases a final palatal element may show up as in CS 14 nây, 36 nyǒmmì, 37 kînbì, or 57 búyì (other examples in CS 40 and 48; the analysis of 54-56 is uncertain). Most probably these palatal segments have to be taken as reflexes of the *ki determiner after elision of the velar stop. The final vowel length in CS 34 bòlè: and 35 hyèlèr might call for the same explanation (see comment concerning the parallel singular forms in $\S 4.5)$.

As for Zan Gula forms, they nearly systematically display a final $-y$ or $-i$ that is evidence of the historical presence of *ki, e.g. CS 13 maay, 29 korey, 36 nyomi, 40 toy, or 57 bii. Exceptions are limited to CS 41 fili and 56 suuli (both contrasting with 42 tokiy).

Reflexes of *-I ki are illustrated in CS 39. Remember that reflexes of the same historical determiner *ki have also been commented on the occasion of class ${ }_{-}\left(m_{1}-\right) r i k i$ above.

\subsection{Historical stacking and $* k V$ type determiners}

Regardless of limited exceptions or irregularities, historical stacking may be viewed as a general explanation for the Group A reflexes of determiners $* \varepsilon$, $* m \varepsilon$, and $* d u$. In the case of $* k \varepsilon, * k u$, and $* k i$ on the other hand, indications of historical stacking are often absent, and one may doubt whether the process occurred systematically. It is useful, however, to look into the precise contexts and conditions where reflexes of the historical determiner may be detected. The following remarks can be made. 
1. Reflexes of $* k \varepsilon$ always have the form $-(C) e / \varepsilon / a$ (perhaps also lengthened $-a^{*}$ ?) (in case of class ${ }^{*} A_{-} k \varepsilon$ ), or $-w \varepsilon$ (for class $*_{-} U_{-} k \varepsilon$ ). Reflexes of * $k u$ show as $-w$ or $-u$ (maybe also $-o$ in CS 47?). Lastly reflexes of *ki have the form $-y,-i,-(m) i$, or $-y i$ (perhaps also lengthened $-e:$ ?). In other words, after occupying a stable intervocalic position as a consequence of historical stacking, the original voiceless velar stop * $k$ - of the determiner is sometimes assimilated or weakened $(-(m) e / \varepsilon / a,-w \varepsilon,-(m) i,-y i)$ but, in most cases, totally lost, a phonetic change that is not infrequent cross-linguistically.

Indeed, a quick search on the Web showed that a regular loss or deletion of intervocalic $-k$ - is attested in such various languages as Sanskrit (Pant 2000: 356) or Prakrit (Ollett 2016: 136), in the Papua New Guinea languages Manambu (Aikhenvald 2008: 56) or Kyaka (Franklin 2016: 145), in Turkish (Sanders 2003: 202-207), and in the Oapan variety of Nahuatl (Amith n.d.: 2). Moreover, the historical change $*_{-} k->\varnothing$ (through a likely path ${ }^{*} k->h_{-}>\emptyset$ ) is typical of several "Sara" languages of Southern Chad (Sar, Mbay, Ngambay, 'Bejond, Kaba of Paoua, Northern and Central 'Dem) that are spoken in the neighbourhood of the Bua Group (Boyeldieu, Nougayrol \& Palayer 2006).

Focussing more precisely on Adamawa-Gur, $-k$ - deletion is attested in the nominal suffixes of Kusuntu, a Gurunsi language of Togo: two series of class agreement markers, namely $1 . k \grave{u},-k \grave{u}, k u ́-, k v-,-k \grave{j}$, and 2. $k a ̀,-k \grave{\varepsilon}, k a ́-, k a-,-k a ̀ ~(=S u b j e c t$ pronoun, Object pronoun, Demonstrative, Determiner, Adjective concord), correspond to nominal suffixes 1. -ô or -óò, and 2. -à or -ø respectively (Kleinewillinghöfer n.d.). In Vere, an Adamawa language of Nigeria/Cameroon, noun suffixes of class $\mathrm{K}$ are represented by $-k$ or $-k p$, as well as by $-a$ or $-\emptyset$ according to the lexical unit (Kleinewillinghöfer 2018). Similarly, the class K noun markers of Waja (Adamawa, Nigeria) are represented either by -gù or by -ù depending on the noun (Kleinewillinghöfer 1996: 29). These last cases are significantly reminiscent - both phonetically and functionally of the situation that may be observed in the Bua languages of Group A. ${ }^{10}$

${ }^{10}$ The present argumentation is based on the assumption that the historical determiners under discussion have to be reconstructed with an initial voiceless 
2. Traces of a historical determiner usually appear in contexts where they contrast with a preceding segment, namely as a vowel after a consonant (e.g. CS $36-m \varepsilon /-m i, 51-b u$ ), or as an approximant following a vowel (e.g. CS 14 -ey/ai/ay, 40 -ow, 48 - $\varepsilon: w, 49-50$-aaw). Zan Gula final $-y$ appears as the regular reflex of *ki in nearly all series and it can follow any front, central or back vowel (e.g. CS 13 maay, 15 ley, 29 korey, 40 toy, and even 42 tokiy).

3. The traces of historical stacking look rather random in relation with series and languages, which makes it difficult to confidently identify cases where stacking did not take place. Considering that the determiner vowel often harmonized with the presumed suffix or final vowel of the noun - namely $-a,-\varepsilon$, or $-e$ in the case of $*_{-} A_{-} k \varepsilon,-U$, $-o$, or -0 , in the case of ${ }^{*} U_{-} k u$, and $-e$ or $-i$ in the case of ${ }^{*} I_{-} k i-$ it seems quite plausible that, after the loss of $* k$-, the determiner vowel simply merged with the noun final vowel with which it came in direct contact. In such a scenario, historical stacking could have actually happened with every noun but not be detectable any more in many cases.

\section{Group B languages}

Although represented here by Lua, Bon Gula, and Bolgo only, Group $B$ languages are more numerous and, with respect to the number marking of nouns, much more varied than the languages of Group A, a situation that results both from the diversity of marking devices and

velar stop $(* k \varepsilon, * k u$, and $* k i)$, which is the most plausible hypothesis for now although it rests upon the evidence of Kulaal only. Now, the phonological analysis proposed by Pairault (1966: 422; 1969: 44) for this language might be debatable: while other Bua languages have, in the initial position, a phonological contrast $/ k-/ v s . / g-/$ that is neutralized as $[-g(-)]$ in internal and final position, Kulaal is described as having one only velar stop phoneme, $/ \mathrm{k} /$, complementarily realized as $[k-]$ and $[-g-]([-g(-)]$ ?) (see also BKKL 2018: 65). In case the historical determiners proved to be better reconstructed with a voiced velar stop (i.e. as * $g \varepsilon$, $* g u$, and *gi) the hypothesis of a total lenition of the consonant, without being necessarily excluded, should at least be justified by different arguments. 
from the fact that class/gender shifts as well as analogical morphological changes most probably occurred in many cases. While agreement is no longer functional in Zan Gula, Fanya and Kulaale, the three languages nonetheless remain close to Kulaal at least in their form. In contrast, Lua, Bon Gula and Bolgo look more distant and their affiliation to the current reconstruction of historical class markers is much more tentative.

Although these languages often look as if their number markers are better compared to the bare suffixes of Kulaal, some data nevertheless point to likely cases of historical stacking. They are examined in the present section.

\subsection{Gender *-l_l$l \varepsilon / *_{-} n_{-} d u$}

According to CS 1-2 and 7-8 Lua forms are mainly marked with $-l$ or -la in the singular vs. -ri in the plural (CS 6 níri might also represent a plural-only form). There is partial complementarity between sg. $-l$ and -la: the latter appears only after closed vowels $(i, u)$. But the reverse is not true so that the -la form is not predictable. In addition comparative data clearly show that CS 4 ?án / ánngú historically results from a former *?ắll / án-ngí, CS 13 máan from *má:l, and CS 5 sià̀l / sè̀l, sì̀l from *sià:l / sè̀n, sìnn. Indeed, most Lua instances of a former *-l/-n alternation have been subject to back formation and aligned with either the sg. or the pl. form (an exception is băl / bàn 'post, pole', cp. Kulaal páál (è) / páán (țù) 'door post'). So, Lua has mainly three types of devices reflecting this gender, namely $-l /-n,-l /-r i$, and -la/-ri. Both $-l a$ and $-r i$ suggest a process of historical stacking.

Bon Gula has mainly $-l /-n$ alternations (CS 9, 13), with no trace of the determiners ${ }^{*} l \varepsilon / * d u$. But CS 6 nir (a likely plural-only form) and the CS 3 plural variant iiri 'face' might represent reflexes of the whole formula *-n_du and point to isolated cases of historical stacking (?).

Notwithstanding the vowel qualities $i$ or $I$, Bolgo has consistently $-l /-d i,-l /-n d i,-l /-r i(C S 1-2,4,8,13,15)$ or $-d /-d i(C S$ 6-7) when Kulaal has final/suffix alternations $-l /-n$ or $-t /-n$, respectively. Con- 
sidering that $-d i$ and variants are likely to represent reflexes of ${ }^{*} n \_d u$ rather than the bare suffix ${ }^{*} n$, historical stacking would have systematically taken place in the plural forms — but not in the singular ones?

Reflexes of gender ${ }^{*}-l_{-} l \varepsilon /{ }^{*}-n_{-} d u$ are summarized in CS 10-11.

\subsection{Gender *-m $m_{1-} m \varepsilon / *^{*}\left(m_{1}-\right) r i \_k i$}

CS 16, 18-19, 21 and 24 indicate Lua sg. $-m$ or $-m a$ that parallel the distribution of $-l$ and -la above: the vowel $a$ appears only in the context of a preceding high vowel (e. g. CS 18 hímá and, not illustrated here, húmá 'milk') but the reverse is not true (e.g. CS 19 nimm, CS 24 sím 'smoke'). Plural forms (25-26) are commented below. Historical stacking might have occurred in the singular -ma forms.

Bon Gula reflexes of * $m_{1-} m \varepsilon$ always have the form -m (CS 16-17, $22,24)$ and plural shows as $-r \varepsilon$ (CS 18). No historical stacking is obvious. The form -rke (CS 25) is commented below.

Bolgo consistently has sg. - $m$ (CS 16-17, 19-21, 22-24), and plural forms appear as -ri (CS 18, 26). Here also there is no indication of a historical stacking process.

The three languages display further plural forms of the -rke or -rgi type (CS 25-26, which in fact represent the only plural forms attested in Lua). Although it is not totally excluded that these sequences historically originated from the stacking of both suffix *-ri and determiner *ki, they more likely result from the suffixation of a later plural suffix *-gI? that does not belong in the class system (BKKL 2018: 116-117).

Reflexes of gender ${ }^{*}-m_{1-} m \varepsilon /{ }^{*}-\left(m_{1}-\right) r i-k i$ are summarized in CS $27-28$.

\subsection{Class *-A_ke}

In the three languages, examples mainly show reflexes $-a$ (Bolgo $-a / \wedge)$ (CS 30-31, 33-35) or $-m$ (CS 36) that are similar to the bare final / suffix of Kulaal. 
However, unlike CS 36 nàm, final - $a$ in Lua cìbà (CS 37) might be explained as a trace of the determiner *ke (cp. the cognates Kulaal

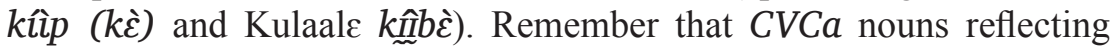
both *-l_le and ${ }^{*}-m_{1-} m \varepsilon$ classes above always contain a high vowel in the first syllable $(\mathrm{Ci} / \dot{i} / \mathrm{uCa})$, a feature that could explain the clear Lua tendency to preserve a final $-a$ as a reflex of historical determiners $* l \varepsilon$

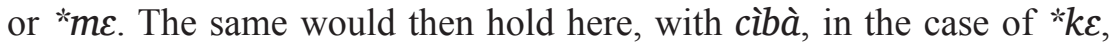
a further $\mathcal{\varepsilon}$-vowel determiner.

Reflexes of class *-A_kE are illustrated in CS 38.

\subsection{Class *-U_ku}

For Class *- $U_{-} k u$ also the languages usually display the same final as in the bare form of Kulaal, i.e. a back vowel (CS 40-43, 45, but no evidence in Lua), or -a (CS 47, 52), or a labial stop in Lua (CS 51). In 52, Bon Gula yaako or yákù suggests historical stacking (cp. Kulaal lá (kÙ)) but the case is isolated and its interpretation doubtful. Reflexes of class *-U_ku are illustrated in CS 53.

\subsection{Class *-U_ke}

The few presumed reflexes of a $*_{-} U_{-} k \varepsilon$ class are not coherent enough to deserve serious comment (see limited summary in CS 58).

\subsection{Class *-I ki}

Lua and Bon Gula usually have a final $-i$ or $-e$ that is similar to the final / suffix vowel of Kulaal (CS 31, 33-35, 41-42, 47, 56). Bolgo has mainly -in (CS 29-30, 33-34, 41, 56?), the origin of which is unknown. Specific comments are as follows.

- In Lua, CS 31 kiängō / kîngō is apparently suffixed both in the sg. and in the pl.; CS 36 nàm and 37 cibì display the same contrast as the corresponding singular forms, nàm and cìbà: only the latter seems to reflect the historical determiner, here *ki; CS 48 píng in includes a plural suffix (cp. CS 4, 16, and 25-26 above). 
- Bolgo CS 36 nèmí, unlike other languages, displays a final -i that suggests historical stacking.

- In CS 54 the plural forms of the three Group B languages, ending with $-w / u$, do not show any trace of historical stacking.

Reflexes of Class ${ }_{-} I_{-} k i$ are illustrated in CS 39.

\subsection{Stacking or not stacking?}

To summarize what we can say about Group B languages, there are serious hints for recognising certain cases of historical stacking (in particular Lua -ri and Bolgo $-d / r i$ as reflexes of plural class * ${ }_{-}-d u$, and probably Lua $-l a,-m a$, and $-a$ as non-systematic reflexes of the three singular classes ${ }^{*}-l_{-} l \varepsilon,{ }^{*} m_{1-} m \varepsilon$, and $\left.{ }^{*}-A_{-} k \varepsilon\right)$. A few further, isolated cases have been mentioned but at least for the time being, and unlike what was said of Group A languages, there are no reasons here to think that historical stacking applied systematically, even with effects that are no longer perceptible. In fact, Group B languages require a thorough analysis where every comparative series will be treated and analyzed case by case, with respect to the different devices displayed by each language.

\section{Conclusion}

The essential consequences of the preceding remarks are as follows.

1. The classes and genders as reconstructed in BKKL (2018) have to be reduced in number (see Table 11):

i) there are no distinct singular classes ${ }^{*}-l$ and ${ }^{*}-l E$ but only one and the same class *-l_le;

ii) the two "complementary" genders *- $l E /{ }^{*}-r U$ and $*_{-}-l /{ }^{*}-n$ are one and the same gender *-l $l_{-} l \varepsilon / *^{*} n_{-} d u$;

iii) lastly, the former ${ }^{*}-l /{ }^{*}-r I$ gender, whose evidence was essentially based on the plural forms $-r i$ and $-d / r i$ of Lua and Bolgo, is itself identified as ${ }^{*} l_{-} l_{\varepsilon} /{ }^{*}-n_{-} d u$.

2. In the current situation we assume that the phonic and morphological material that historically generated the sequences observed in 
the present-day languages was the same as in today's Kulaal. This is obviously questionable but also unavoidable in this first step.

Nevertheless, we can at least show that the representativeness of the different classes/genders was not the same. Table 3 calculates the number of currently identified CS according to the classes/genders involved. Even if the numbers are rather approximative (they include some poorly illustrated series as well as some cases of class/gender shifts), they give a rough idea of the relative frequency of the different types at a proto-Bua stage. ${ }^{11}$

Table 3

\section{Representativeness of identified classes/genders in the current proto-Bua CS database}

\begin{tabular}{|c|c|c|c|}
\hline sg. & l & pl. & nb. of CS \\
\hline$*_{-} A_{-} k \varepsilon$ & 1 & $*_{-} I k i$ & 22 \\
\hline$*_{-} U_{-} k u$ & 1 & *-I_ki & 28 \\
\hline *-l $l \_\varepsilon$ & 1 & $*_{-} n \_d u$ & 65 \\
\hline *-l $l \_\varepsilon$ & I & - & 6 \\
\hline$*-m_{1} m \varepsilon$ & l & $*_{-}\left(m_{1}-\right) r i \underline{k i}$ & 14 \\
\hline$*_{-} U_{-} k \varepsilon$ & 1 & ${ }_{-} I_{-} k i$ & 5 \\
\hline *-l_lle & 1 & ${ }_{-} I_{-} k i$ & 3 \\
\hline Total & & & 143 \\
\hline
\end{tabular}

Table 2 showed that most frequent genders of Kulaal are kù/kì, $k \varepsilon / k i$, and lì/țv̀ (respectively 332, 240, and 144 (227?) tokens out of a total of 1022 (1136?) nouns with identified determiners). In contrast, proto-Bua * ${ }^{\prime} l \varepsilon /{ }^{*}-n_{-} d u$ was markedly predominant. Indeed, present-day $k \dot{u} / k i$ and $k \varepsilon / k i$ represent the most (the only?) active genders of Kulaal, which namely work as reception genders for recently borrowed items (see 2 ).

${ }^{11}$ Class *- $l \_l \varepsilon /-$ represents singular-only CS whose plural is unknown. Gender ${ }^{*}-m_{1-} m \varepsilon /{ }^{*}-\left(m_{1}-\right) r i \_k i$ represents CS whose identity is unambiguous but whose actual reflexes are mostly either singular or plural. 
3. Regarding noun class morphology, Kulaal, Zan Gula, and Fanya/ Kulaale clearly represent the closest and most consistent subgroup within the Bua languages. Interestingly this situation conforms with the lexical distances calculated by Raimund Kastenholz (Kastenholz 2017: 2; BKKL 2018: 60). Furthermore the four languages occupy a central position in the Bua geographical area, around which outer languages, such as Lua, Bon Gula, and Bolgo display more altered and more diversified reflexes of the historical noun morphology, a development that was perhaps favoured by their direct contact with languages from other families (in particular Eastern Chadic, Central Sudanic $(\mathrm{SBB})$, as well as the isolate Laal). 


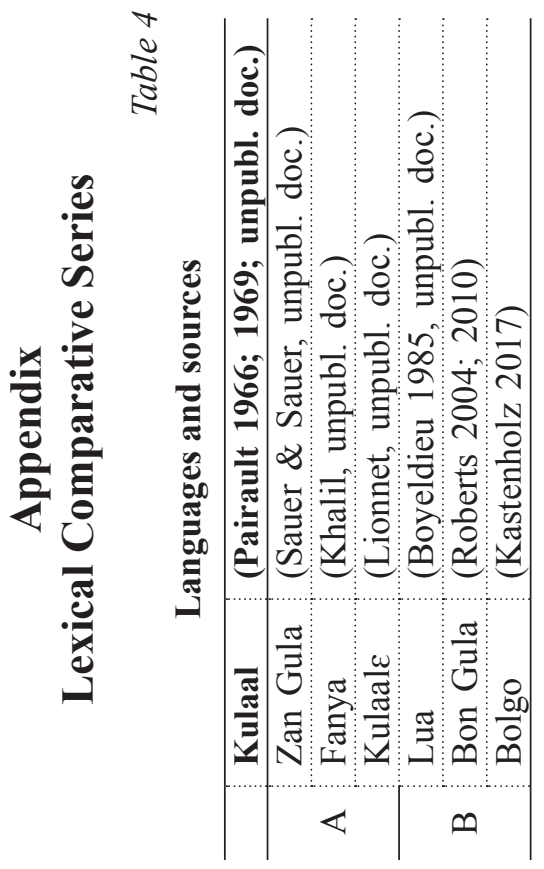

$\frac{0}{\frac{0}{0}}$

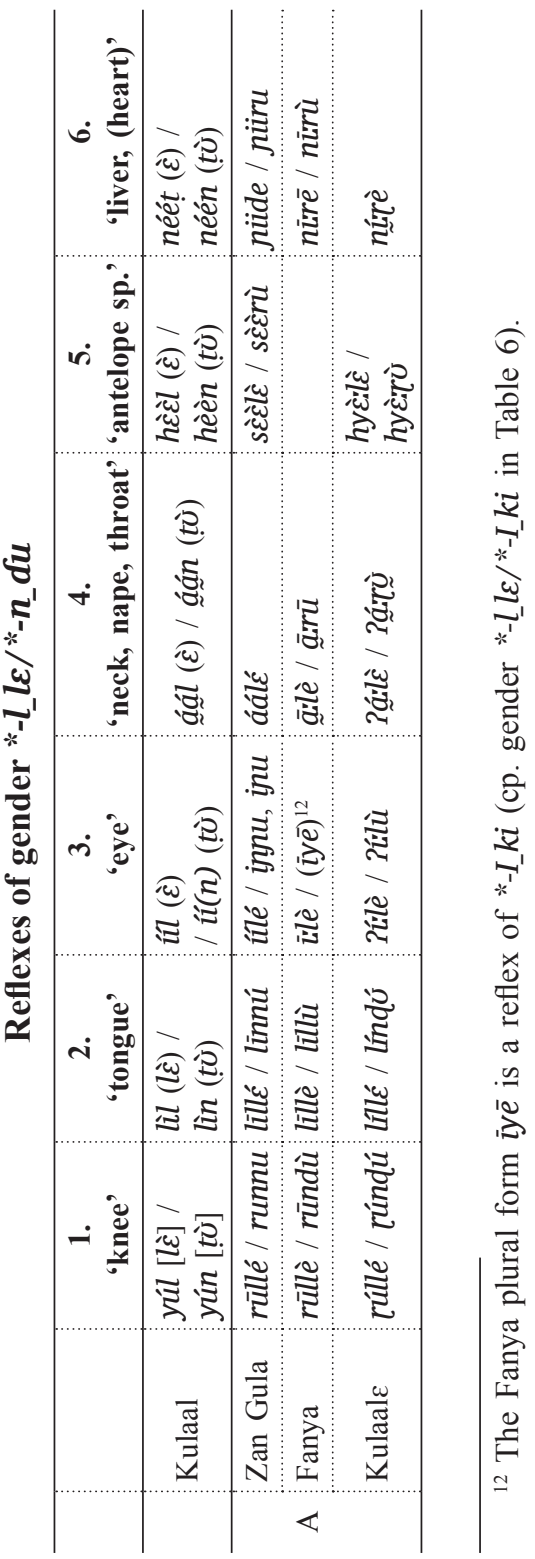




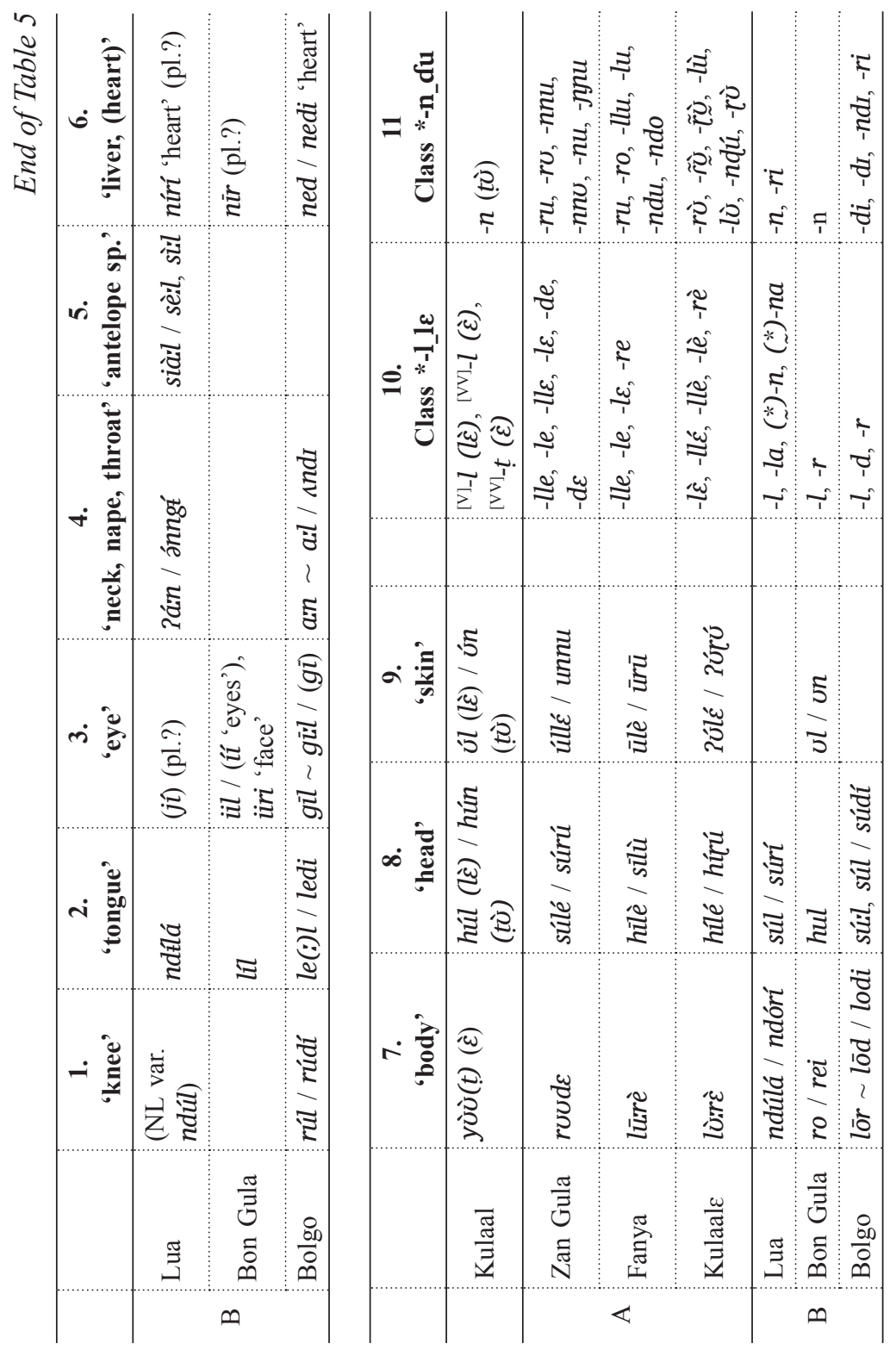




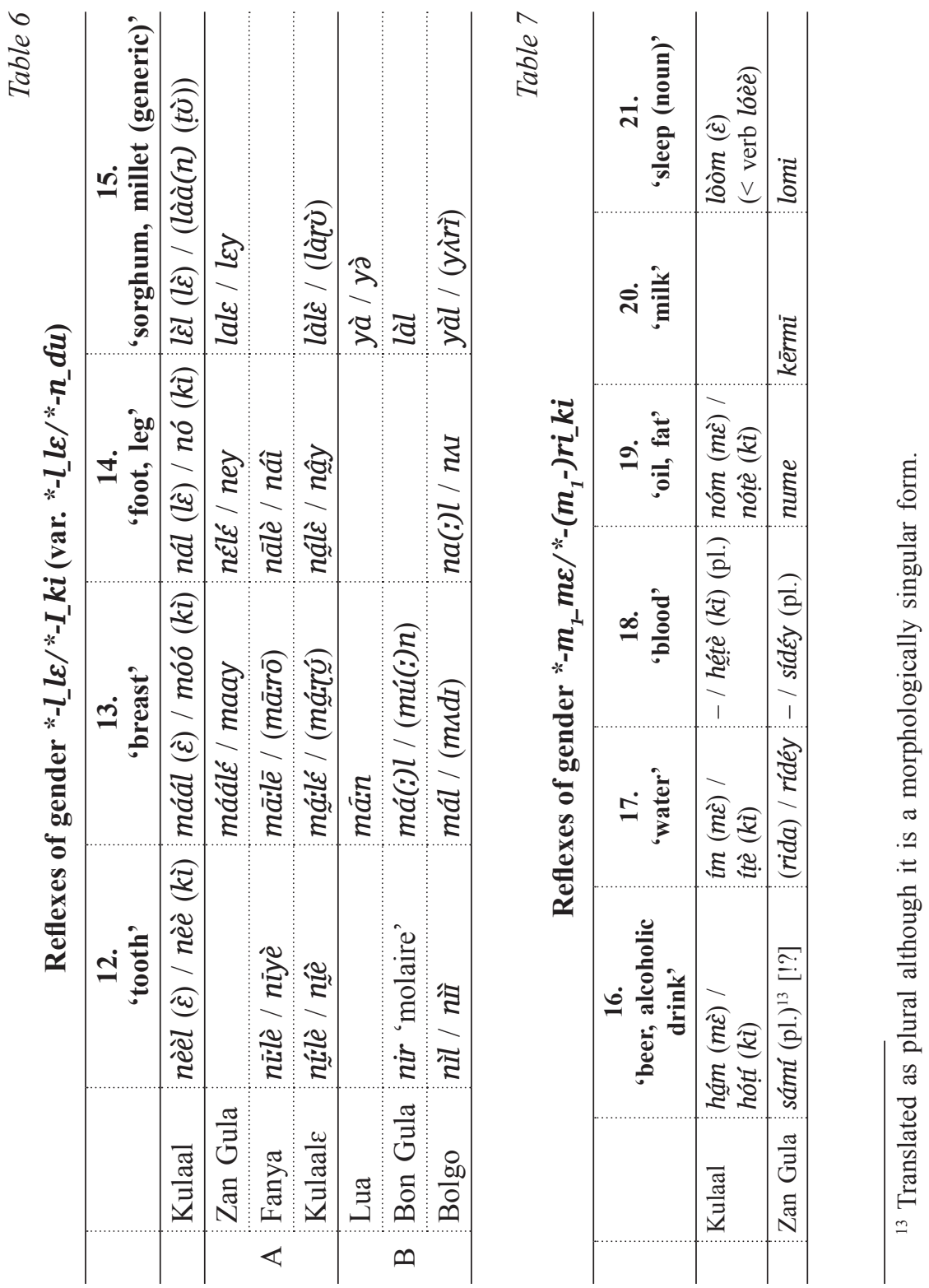




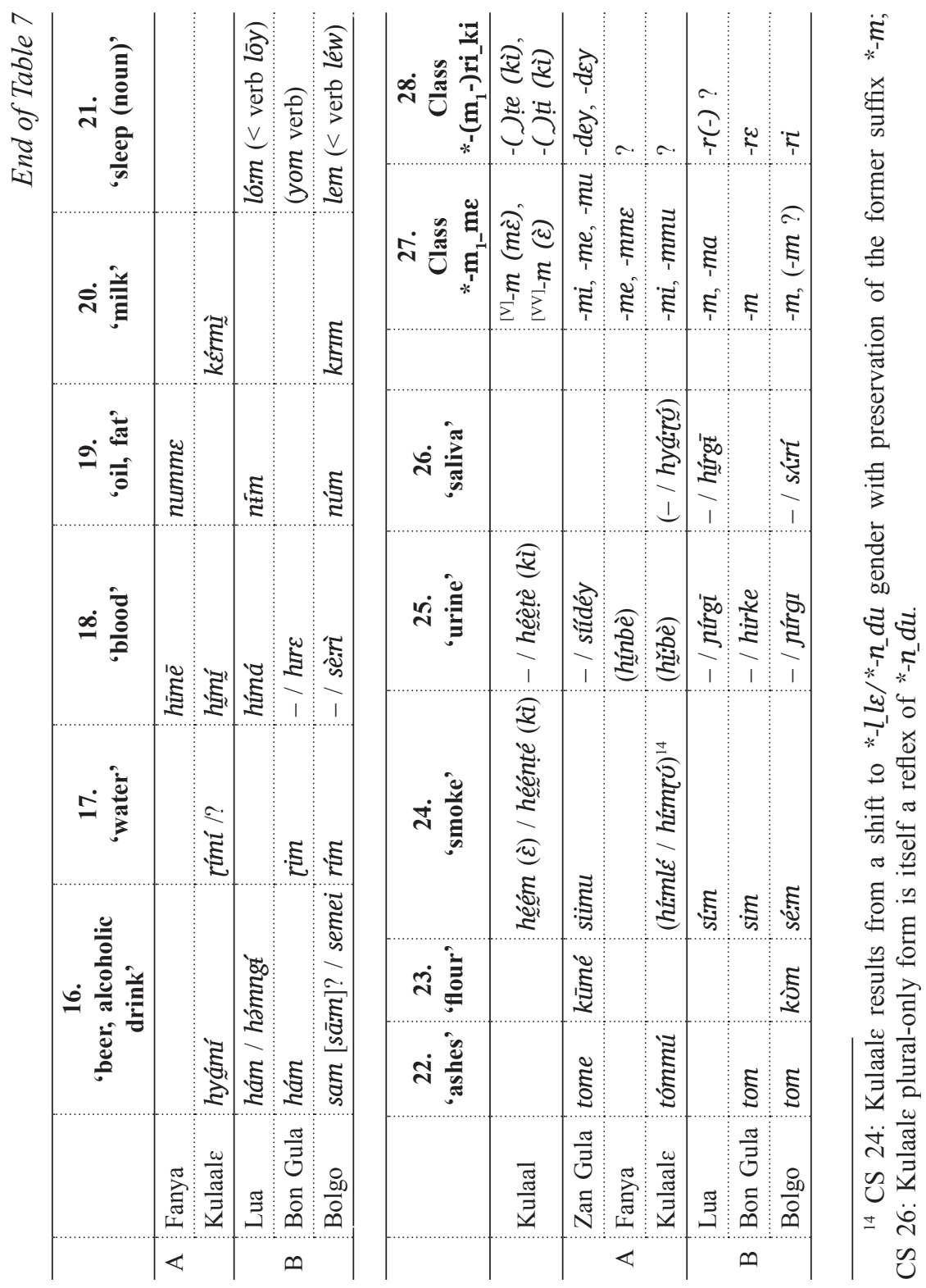


$\infty$
0
$\frac{0}{0}$
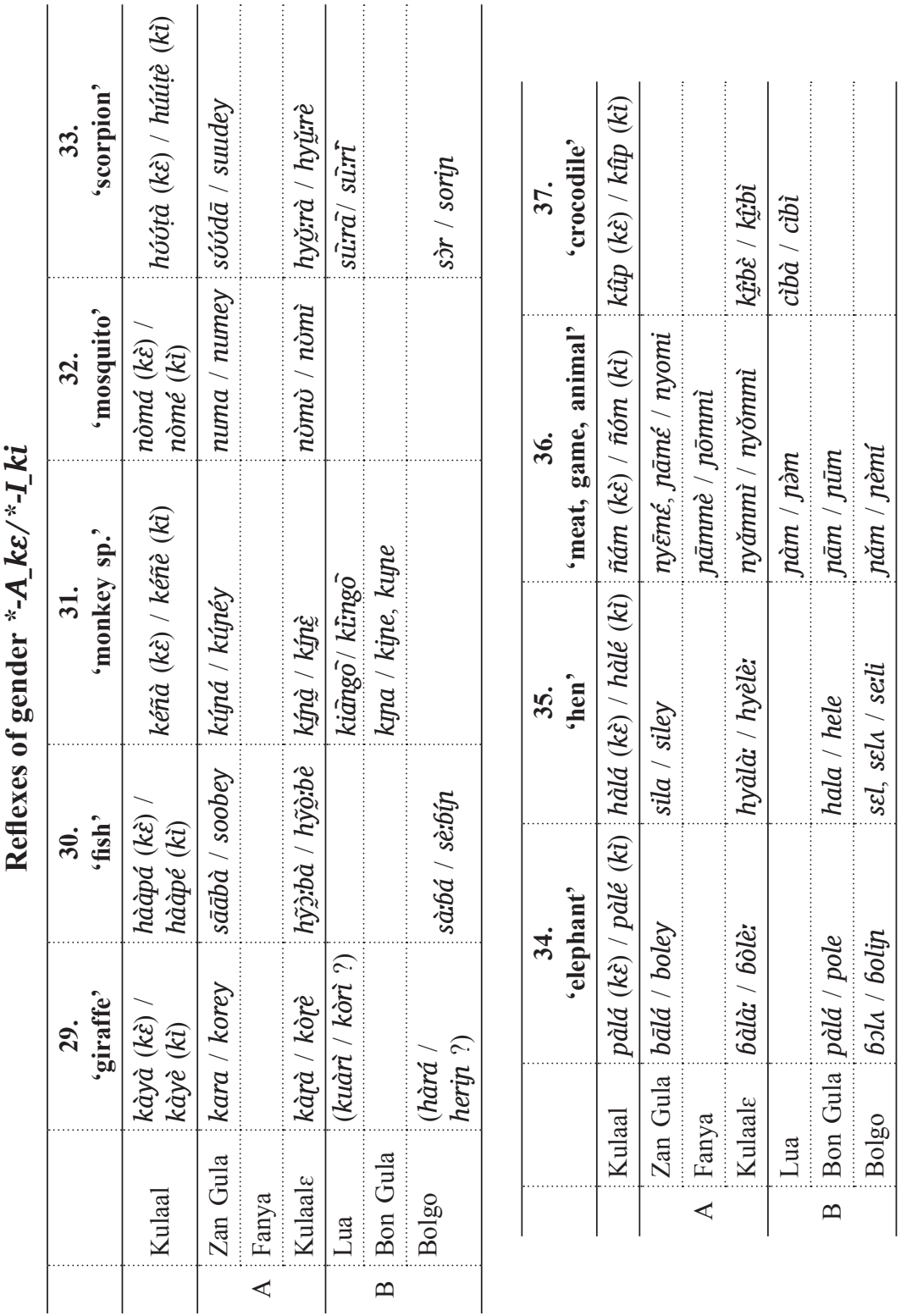


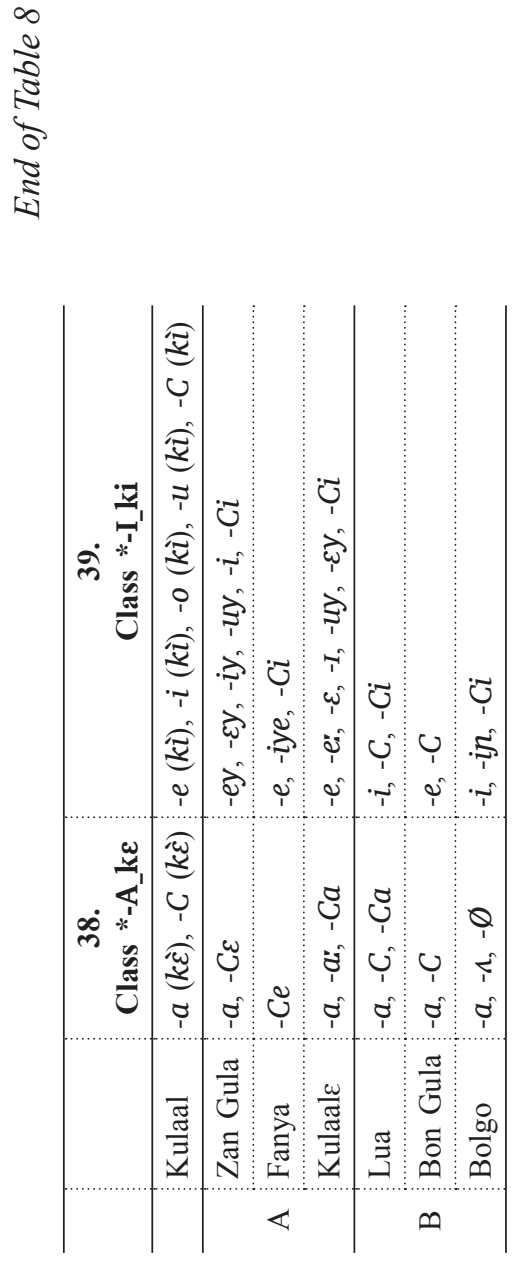

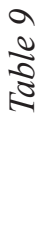

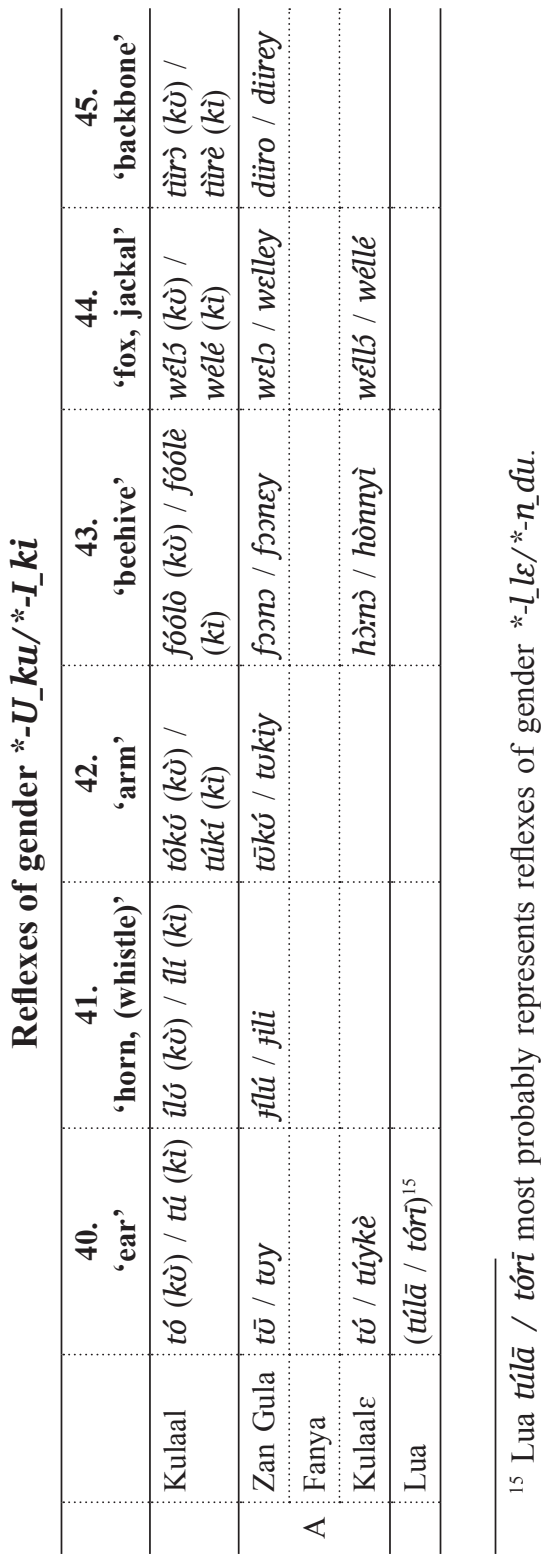




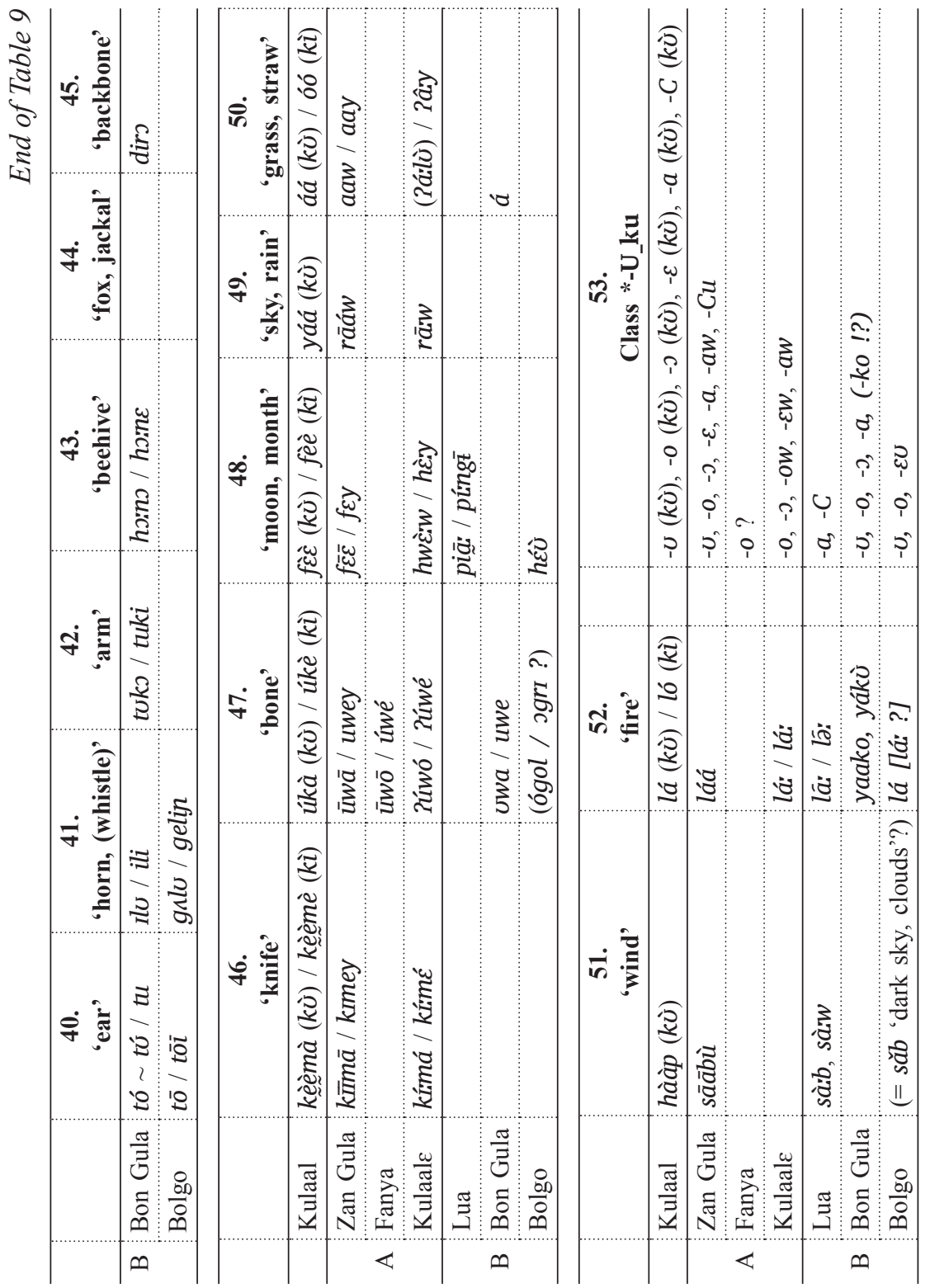




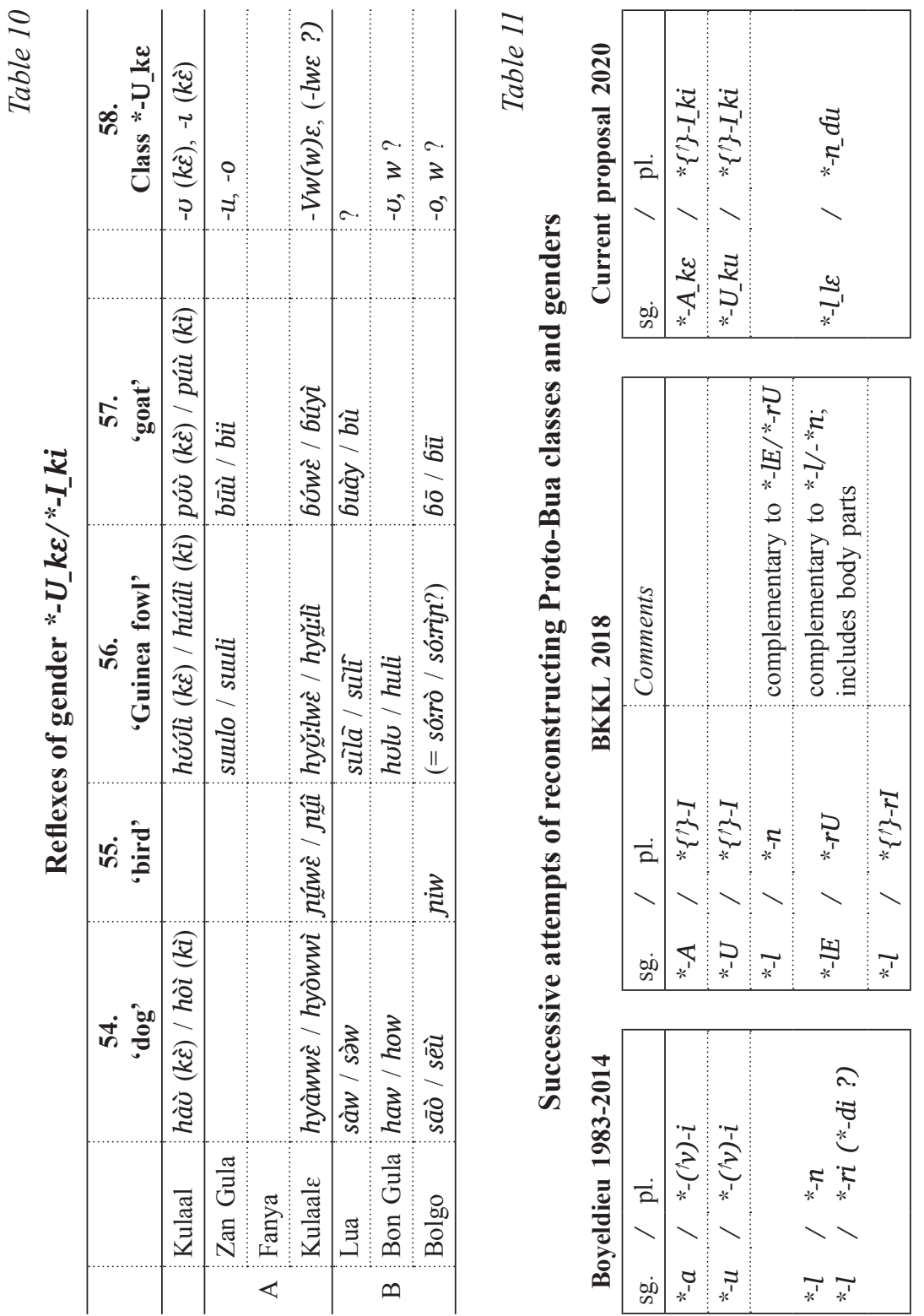



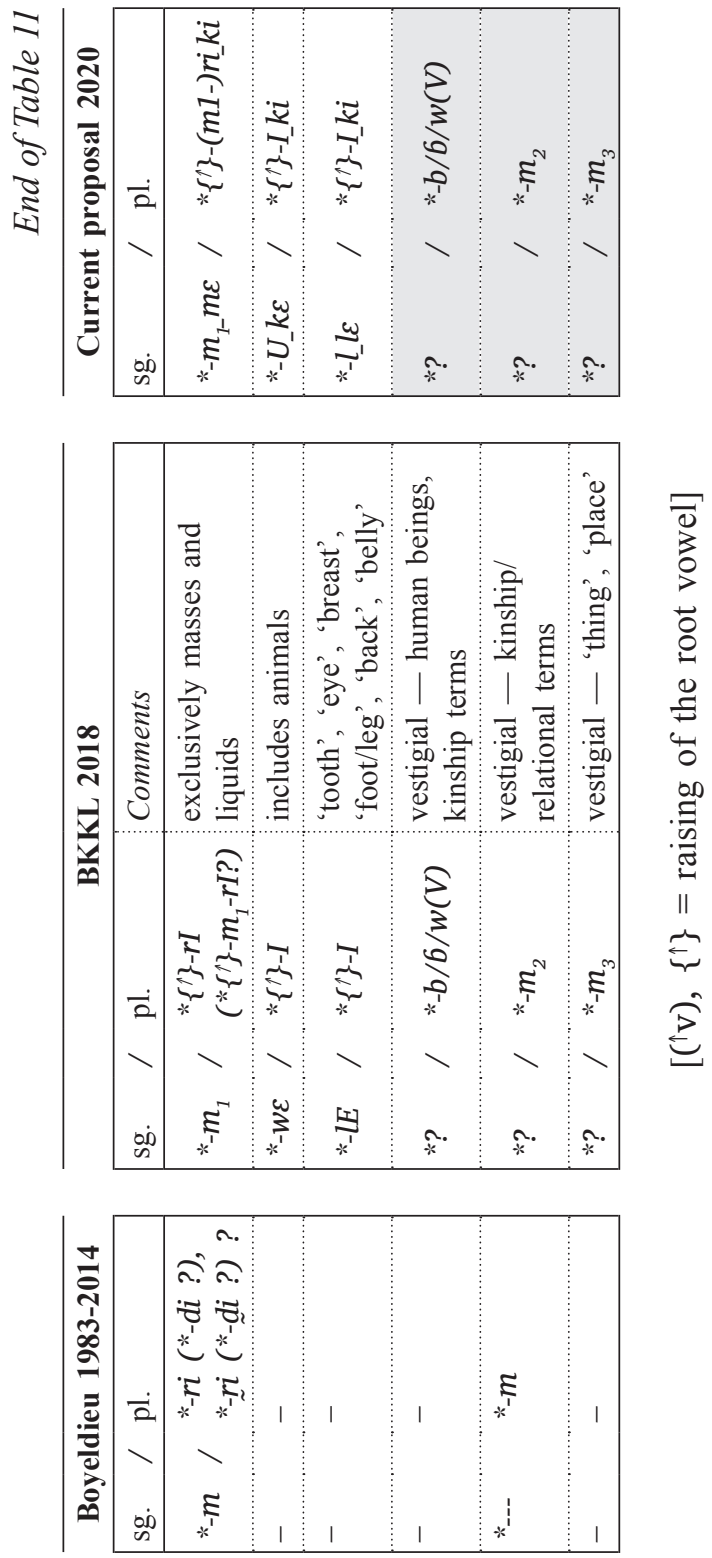


\section{References}

Aikhenvald, Alexandra Y. 2008. The Manambu language of East Sepik, Papua New Guinea. Oxford - New York: Oxford University Press.

Amith, Jonathan. n.d. Tonogenesis and reduplication in Balsas River Nahuatl

of Central Guerrero. Mexico. https://cpb-us-w2.wpmucdn.com/ campuspress.yale.edu/dist/4/1207/files/2015/10/Amith_SSMCA-1m6684e. pdf (consulted 25/08/2019).

BKKL 2018: see Boyeldieu, Kastenholz, Kleinewillinghöfer \& Lionnet. 2018.

Boyeldieu, Pascal. 1983. Vestiges de suffixes de classes nominales dans les langues du groupe Boua (Tchad, Adamawa-13 de J.H. Greenberg). In Kaye, Jonathan \& Koopman, Hilda \& Sportiche, Dominique \& Dugas, André (eds.), Current approaches to African linguistics. Vol. 2, 3-15. Dordrecht - Cinnaminson: Foris Publications.

Boyeldieu, Pascal. 1985. La langue lua (" niellim ») (Groupe BouaMoyen-Chari, Tchad). Phonologie. Morphologie. Dérivation verbale. Paris: SELAF. (Descriptions de Langues et Monographies Ethnolinguistiques 1).

Boyeldieu, Pascal. 1986. La formation du pluriel nominal en kulaal (Tchad):

Essai de systématisation des documents publiés par C. Pairault. Afrika und Übersee 69(2). 209-249.

Boyeldieu, Pascal. 2014. Les langues du groupe boua (Adamawa 13 de J.-H. Greenberg). (Paper presented at the seminar "Linguistique comparative historique au XXI siècle: enjeux théoriques et méthodologiques", Paris, 25 March 2014.)

Boyeldieu, Pascal \& Nougayrol, Pierre \& Palayer, Pierre. 2006. Lexique comparatif historique des langues sara-bongo-baguirmiennes. Paris: CNRS-LLACAN. http://sumale.vjf.cnrs.fr/SBB/

Boyeldieu, Pascal \& Kastenholz, Raimund \& Kleinewillinghöfer, Ulrich \& Lionnet, Florian. 2018. The Bua group languages (Chad, Adamawa 13): A comparative perspective. In Kramer, Raija \& Kießling, Roland (eds.), Current approaches to Adamawa and Gur languages, 53-126. Köln: Rüdiger Köppe. (Afrika und Übersee, Beiheft 34.)

Franklin, Karl J. 2016. Some observations on Kyaka-Kewa cognates. Language \& Linguistics in Melanesia 34(1). 140-159. 
Houis, Maurice. 1967. Apercu sur les structures grammaticales des langues négro-africaines. Lyon: Faculté de théologie S.J.

Kastenholz, Raimund. 2017. La langue bolgo du Guéra (Tchad): notes de recherche et matériel lexical. Mainz: Johannes Gutenberg-University Mainz. (Working Papers of the Department of Anthropology and African Studies of the Johannes Gutenberg-University Mainz, 172). https:// www.ifeas.uni-mainz.de/files/2019/07/AP172.pdf

Kleinewillinghöfer, Ulrich. 1996. Relationship between Adamawa and Gur languages: The case of Waja and Tula. Cahiers voltaïques / Gur papers $1,25-45$.

Kleinewillinghöfer, Ulrich. [2017]. Nominal classification in Kulaal: the Benue-Volta perspective. Ms.

Kleinewillinghöfer, Ulrich. 2018. Gender in Vere and Atlantika Vere. (Paper presented at the Workshop "Gender across Niger-Congo", Berlin, November 29 2018.)

Kleinewillinghöfer, Ulrich. n.d. Gender in Kusuntu and Bago. Ms.

Ollett, Andrew. 2016. Language of the snakes: Prakrit, Sanskrit, and the language order of Premodern India. New York: Columbia University.

Pairault, Claude. 1966. Boum le Grand: village d'Iro. Paris: Institut d'Ethnologie.

Pairault, Claude. 1969. Documents du parler d'Iro, kùláál du Tchad. Paris: Klincksieck. (Langues et littératures de l'Afrique noire 5).

Palayer, Pierre. 1975. Esquisse phonologique de la langue tounia. In Boyeldieu, Pascal \& Palayer, Pierre (eds.). Les langues du groupe boua: Études phonologiques, 131-195. N'Djaména: INSH. (Études et documents tchadiens, Série C, Linguistique 2.)

Pant, Mahes Raj. 2000. Jātarūpa's commentary on the Amarakoṣa. Part I, Introduction. Dehli: Motilal Banarsidass Publishers.

Roberts, Jim. [2004]. Notes on Bon Gula. [Mongo]. Ms.

Roberts, James, (avec l'assistance de Dewane, Hamdane \& Defalla, Issa). 2010. Esquisse de grammaire Bone Goula (Êeni). (Modifiée par Silke Sauer avec l'assistance de Adum Adef et Breme Outmane), DTL, Mongo. Ms.

Sanders, Robert Nathaniel. 2003. Opacity and sound change in the polish lexicon. PhD. Santa Cruz: University of California. (Ph.D. dissertation.) 


\section{Unpublished linguistic documentation}

Boyeldieu, Pascal: Lua.

Khalil, Alio (University of N'Djaména): Fanya.

Lionnet, Florian: Kulaale.

Pairault, Claude: Kulaal.

Sauer, Silke \& Sauer, Martin: Zan Gula. 